\title{
Sensory Evaluation Attributes of Ginger and Alligator Pepper Treated Dried Beef
}

\author{
Halimatu Isata Lumeh ${ }^{1}$, Saidu Kanu², Olajide Phillip Sobukola ${ }^{3}$ \\ Sierra Leone Agricultural Research Institute, Teko Livestock Research Centre, Makeni
}

\begin{abstract}
The study was carried out at the Department of Food Science and Technology, Federal University of Agriculture Abeokuta (FUNAAB), Ogun State, Nigeria, to investigate attributes of ginger and alligator pepper treated dried beef. Values of GE colour parameters $L^{*} a^{*}$ and $b^{*}$ of the meat were 39.86-63.59, 11.49-19.30 and 11.02-19.41, respectively. Scores of appearance, taste, aroma, texture and overall acceptability were 4.38-7.17, 4.92-7.10, 5.42-6.70, 5.06-6.43, 4.33-6.73 and 5.16-6.90 respectively. Significant $(p<0.05)$ differences were recorded for appearance and the scores of sensory attributes of the products. Drying at higher temperatures above $65^{\circ} \mathrm{C}$ significantly reduced the sensory acceptability of the product $(p<0.05)$. Samples containing GE were more acceptable than those containing AP. Dried meat at 75 and $850 C$ had no viable microbial count. It can be concluded that using $70 \%$ GE and drying at $750 C$ showed greater potential for meat preservation.
\end{abstract}

Keywords: Sensory, attributes, acceptability, ginger, alligator pepper

\section{Introduction}

Meat is defined as the flesh of animals used as food. Fresh meat refers to meat from recently processed animals as well as vacuum-packed meat or meat packed in controlledatmospheric gases, which has not undergone any treatment other than chilling to ensure preservation [25].It is a nutritious, protein-rich food which is highly perishable and has a short shelf-life unless preservation methods are used. It is the first-choice source of animal protein for many people and its consumption is continuously increasing worldwide. Significant portion of meat and meat products are spoiled every year due to microbial spoilage ([10]. Varied nutrient composition of meat makes it an ideal environment for the growth and propagation of meat spoilage micro-organisms and common food-borne pathogens. It is therefore indispensible that sufficient preservation technologies are applied to maintain its safety and quality [3]. The processes used in meat preservation are principally concerned with inhibiting microbial spoilage, although other methods of preservation are sought to minimise other deteriorative changes such as colour and oxidative)[25]. Deterioration of meant and it products is influenced by a number of interrelated factors that influence the shelf life and keeping quality of meat. These include temperature, atmospheric oxygen $\left(\mathrm{O}_{2}\right)$, endogenous enzymes, moisture (dehydration), light and, most importantly, micro-organisms either alone or in combination, can result in detrimental changes in the colour odour, texture and flavour of meat ([8]Although deterioration of meat can occur in the absence of microorganisms (e.g., proteolysis, lipolysis and oxidation), microbial growth is by far the most important factor in relation to the keeping quality of fresh meat [13]

Natural organic products such as spices with antioxidant and antimicrobial properties can serve as alternative to the use of synthetic chemicals preservatives to preserved beef. Ginger (Zingiberofficinale) and alligator pepper (Aframomummelegueta) spices are edible plant materials (leaf in onion and garlic, rhizome in ginger) that have antioxidative, antiseptic and bacterio-static properties when added to foods such as fish, meat delay the onset of rancidity and reduce microbial proliferation and impact flavour to the foods [7, 12]; Ginger is wildly used in the local food industries to improve flavour, shelf-life and consumer acceptability of delicacies [17].Alligator pepper seeds on the other hand have pungent peppery taste due to aromatic ketones [21,9]commonly used across tropical Africa including Nigeria, Liberia, Sierra Leone, Ghana, Cameroon, Cote D'ivoire and Togo. Several research has been conducted using both natural and synthetic preservatives in the preservation of meat and meat products. Alligator pepper and ginger are important spices known for characteristic anti-tumor, anti-proliferative, amphitensive, larvicidal and nematicidal properties due to its 6-gingerol, 6-paradol, shagaols and zingiberene content. The presence of phenolic compounds in the seed of Alligator pepper and Ginger indicate that these plants are antimicrobial agents and this is because phenols and phenolic compounds have been comprehensively used in disinfections and remain the standard with which other bactericides are compared. Therefore, evaluating the preservative efficacies of these substances and their possible effects on freshly-processed and dried beef quality cannot be overstated

\section{Materials and Methods}

The study was conducted at the Department of Food Science and Technology, Federal University of Agriculture Abeokuta (FUNAAB), Ogun State, Nigeria from November 2014 till April, 2015.

\section{Source and preparation of the meat used}

Meat used for this experiment comprised of cut from the thigh region of a male healthy cow slaughtered in a certified abattoir at Kuto market, Abeokuta, Ogun State. The animal was subjected to slaughtering through the use of a sharp knife driven across the neck region of the animal and it was laid flat on clean polythene while blood was allowed to drain completely from the carcass for fifteen (15) minutes. Afterwards, the carcass was de-skinned, eviscerated and deboned while flesh was cut into one-kilogram in separate well-labelled bags. One hundred (100) gram of fresh

\section{Volume 6 Issue 12, December 2017}




\section{International Journal of Science and Research (IJSR) \\ ISSN (Online): 2319-7064}

Index Copernicus Value (2016): 79.57 | Impact Factor (2015): 6.391

beef cut from the thigh region was cut into $1 \times 5 \times 10 \mathrm{~cm}$ size in length, width and thickness on a sterile glass surface using a sharp knife. Adequate care was ensured to prevent contamination at every point of post-slaughtering handling.

\subsection{The source and Preparation of Alligator Pepper and Ginger Powder}

Dried alligator pepper and fresh rhizomes of ginger were sourced from local farmers in Kuto market, Abeokuta. The processing of powder from fresh sample was achieved using the method of [2] as described by [1]. Ginger (Zingiberofficinale) rhizomes were peeled while alligator pepper (Aframomummelegueta) seeds were removed from the pods, sorted and cleaned from all extraneous materials and adhering particles. The samples were oven-dried in a hot air oven and crushed using an electric grinder 5 speed blender, (Model: BBEK1051 RSH 0005494-124, Rank sharp industries Ltd, 1801). Ground samples were soaked in equal volume of distilled water for twenty-four hours for maximum extract recovery as described by [6].

Preparation of Alligator pepper and Ginger suspension

One hundred percent $(100 \%)$ of the resulting powder crude extract of alligator pepper and ginger was prepared using the prescribed method of [11] by weighing the alligator pepper and ginger powder using a sensitive electronic scale (AND EK-4100i, A\&D CO.LTD JAPAN). Equal volume $(\mathrm{cm} 3) /$ weight $(\mathrm{g})$ of distilled water and ground sample of the plant materials at one hundred millilitre $(100) \mathrm{mL}$ ) was poured into one hundred gram $(100 \mathrm{~g})$, then, the samples were then dissolved into an Erlenmeyer flask separately and labelled accordingly. These were left to rest for twenty four (24) hours for proper dissolution. Thereafter, dilution was done with varied proportion of distilled water making it each up to $100 \mathrm{~mL}$ volume.

\subsection{Experimental Design}

The treatments consisted of two spices; alligator pepper and ginger. The spice were diluted with distilled water at concentration levels of 70: 30 and 50: $50 \mathrm{v} / \mathrm{v}$ respectively, while the untreated samples immersed in distilled water served as control. The soaked beef cuts were then dried at varied temperature 65,75 and $85{ }^{\circ} \mathrm{C}$ in a locally-fabricated convective dryer for 18 hours till the samples were completely dried.

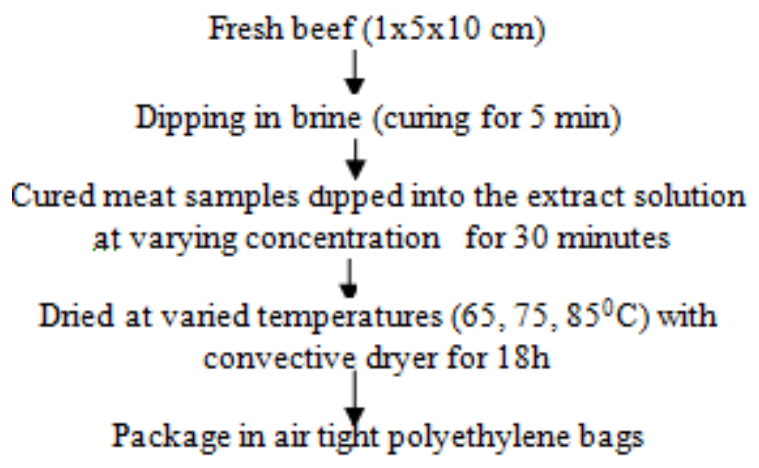

Figure 1: Flow Chart for Meat Treatment and Drying [5]
Table 1: Layout of the Experiment

\begin{tabular}{|r|c|c|}
\hline \multicolumn{1}{|l|}{ Spice } & Concentration & Temperature \\
\hline Control & 100 & $65^{\circ} \mathrm{C}$ \\
\hline GINGER $\left(\mathrm{G}_{1}\right)$ & $70: 30$ & $65^{\circ} \mathrm{C}$ \\
\hline GINGER $\left(\mathrm{G}_{2}\right)$ & $50: 50$ & $65^{\circ} \mathrm{C}$ \\
\hline$\left(\mathrm{G}_{1}\right)$ & $70: 30$ & $75^{0} \mathrm{C}$ \\
\hline$\left(\mathrm{G}_{2}\right)$ & $50: 50$ & $75^{\circ} \mathrm{C}$ \\
\hline$\left(\mathrm{G}_{1}\right)$ & $70: 30$ & $85^{\circ} \mathrm{C}$ \\
\hline$\left(\mathrm{G}_{2}\right)$ & $50: 50$ & $85^{\circ} \mathrm{C}$ \\
\hline ALLIGATOR PEPPER $\left(\mathrm{A}_{1}\right)$ & $70: 30$ & $65^{\circ} \mathrm{C}$ \\
\hline ALLIGATOR PEPPER $\left(\mathrm{A}_{2}\right)$ & $50: 50$ & $65^{\circ} \mathrm{C}$ \\
\hline$\left(\mathrm{A}_{1}\right)$ & $70: 30$ & $75^{\circ} \mathrm{C}$ \\
\hline$\left(\mathrm{A}_{2}\right)$ & $50: 50$ & $75^{\circ} \mathrm{C}$ \\
\hline$\left(\mathrm{A}_{1}\right)$ & $70: 30$ & $85^{\circ} \mathrm{C}$ \\
\hline$\left(\mathrm{A}_{2}\right)$ & $50: 50$ & $85^{\circ} \mathrm{C}$ \\
\hline
\end{tabular}

\subsection{Laboratory Sensory Acceptability Test of the Treated Dried Beef Samples}

Laboratory sensory acceptability evaluation of the preserved beef was conducted in line with the method of [18]. A questionnaire which comprised of health-related information was prepared as olfactory cells like taste bud could have been affected by the use of narcotics like tobacco, anti-biotis and chemotherapies [14].

\subsection{Colour}

The colour of the dried meat samples were measured using a Konica Minolta Colour Measuring System (Chroma meter CR-410, Minolta LTD Japan) as described by [24]

The lightness $\left(\mathrm{L}^{*}\right)$, redness, $\left(\mathrm{a}^{*}\right)$ and yellowness $\left(\mathrm{b}^{*}\right)$ values were obtained after calibrating the instrument using a white tile. Six replication readings were taken for each spiced and control dried meat samples and the average value reported. The results were expressed in accordance with CIELAB system where:

$\mathrm{L}^{*}$ is known as the lightness [ $\mathrm{L}=0$ (black), $\mathrm{L}=100$ (white)], $a^{*}(-\mathrm{a}=$ greenness,$+\mathrm{a}=$ redness $)$

$b^{*}\left(-b^{*}\right.$ values $=$ blueness,$+b^{*}$ values $=$ yellowness $)$

Selection of panel and sensory evaluation conduction

This trial was aimed at evaluating acceptability of the treated dried beef samples with each of ginger and alligator pepper spices in survey trial. A thirty (30) untrained panellists were randomly selected in the Department of Food Science and Technology, Federal University of Agriculture, Abeokuta. The samples were assessed for the following attributes; appearance, taste, aroma, tenderness, mouth feel and overall acceptability of the processed and dried beef. Each panellist was served with samples of each preserved meat, they were provided with water to rinse their mouth after the tasting of each sample in order to prevent "taste masking".

\subsection{Statistical Analysis}

Data were subjected to statistical analysis using SPSS version 21. Analysis of variance (ANOVA) was used to compare significant means. The Least Significance Difference (LSD) was used to determine the level of significance. 


\section{International Journal of Science and Research (IJSR) ISSN (Online): 2319-7064}

Index Copernicus Value (2016): 79.57 | Impact Factor (2015): 6.391

\section{Result}

3.1. Effect of Spiced, Concentrations and Drying Temperatures on Colour Parameters of The Processed Dried Beef

Table 2 shows the results of colour parameters of the processed and dried beef based on spiced solution concentrations as well as drying temperatures. There were significant differences $(\mathrm{p}<0.05)$ in the mean values of lightness $\left(\mathrm{L}^{*}\right)$, redness $\left(\mathrm{a}^{*}\right)$ and yellowness $\left(\mathrm{b}^{*}\right)$ parameters of the beef samples. Lightness value ranged between 8.43 63.59 , with beef treated with $70 \%$ ginger concentration and then dried at $75 \mathrm{oC}$ had the highest lightness value, while sample treated with $70 \%$ alligator pepper concentration and dried at $85 \mathrm{oC}$ had the least value. In addition, redness parameter of treated and dried beef samples ranged from 5.73-19.30. Sample treated with 70\% ginger concentration and dried at $650 \mathrm{C}$ had the highest redness value $\left(\mathrm{a}^{*}\right)$ $23.63 \%$, while samples treated with $70 \%$ alligator pepper concentration and dried at $75 \mathrm{oC}$ had the lowest value for redness. Yellowness parametres of treated and dried beef samples ranged from 2.81-23 .91. Samples treated with $70 \%$ ginger concentration and then dried at $75 \mathrm{oC}$ and treatment with $50 \%$ ginger concentration dried at $75 \mathrm{oC}$ had similar values and was observed to have the highest, while sample treated with $70 \%$ alligator pepper and dried at $85 \mathrm{oC}$ had the lowest level for yellowness.

Table 2: Effect of Spice, Concentrations and Drying Temperatures on Colour Parameters on the Dried Beef Samples

\begin{tabular}{|c|c|c|c|c|c|c|}
\hline Spice & & Concentration & DryingTemperature $\left({ }^{\circ} \mathrm{C}\right)$ & $\mathrm{L}^{*}$ & $\mathrm{a}^{*}$ & $\mathrm{~b}^{*}$ \\
\hline & Control & & 65 & $27.92 \pm 0.02^{\mathrm{gh}}$ & $11.61 \pm 0.01^{\mathrm{ef}}$ & $19.41 \pm 0.20^{\mathrm{b}}$ \\
\hline & & & & & & \\
\hline GINGER & & $70 \%$ & 65 & $56.05 \pm 0.08^{\mathrm{b}}$ & $19.30 \pm 0.02^{\mathrm{a}}$ & $19.60 \pm 0.00^{\mathrm{b}}$ \\
\hline & & $50 \%$ & 65 & $39.86 \pm 0.95^{\mathrm{f}}$ & $11.49 \pm \mathrm{p} 0.04^{\mathrm{ef}}$ & $19.41 \pm 0.01^{\mathrm{b}}$ \\
\hline & & $70 \%$ & 75 & $63.59 \pm 0.94^{\mathrm{a}}$ & $16.58 \pm 0.08^{\mathrm{b}}$ & $23.91 \pm 0.16^{\mathrm{a}}$ \\
\hline & & $70 \%$ & 75 & $63.59 \pm 0.94^{\mathrm{a}}$ & $16.58 \pm 0.08^{\mathrm{b}}$ & $23.91 \pm 0.16^{\mathrm{a}}$ \\
\hline & & $70 \%$ & 85 & $49.16 \pm 0.18^{\mathrm{d}}$ & $13.97 \pm 0.01^{\mathrm{cd}}$ & $14.28 \pm 0.06^{\mathrm{cd}}$ \\
\hline & & $70 \%$ & 85 & $50.42 \pm 0.03^{\mathrm{c}}$ & $17.45 \pm 0.12^{\mathrm{b}}$ & $11.02 \pm 0.03^{\mathrm{efg}}$ \\
\hline ALLIGATOR PEPPER & & $70 \%$ & 65 & $47.42 \pm 0.03^{\mathrm{d}}$ & $13.97 \pm 0.01^{\mathrm{cd}}$ & $10.93 \pm 0.00^{\mathrm{g}}$ \\
\hline & & $50 \%$ & 65 & $42.36 \pm 0.92^{\mathrm{e}}$ & $11.03 \pm 0.21^{\mathrm{ef}}$ & $9.02 \pm 0.62^{\mathrm{h}}$ \\
\hline & & $70 \%$ & 75 & $25.64 \pm 0.65^{\mathrm{gh}}$ & $9.72 \pm 0.37^{\mathrm{gh}}$ & $11.56 \pm 0.01^{\mathrm{fg}}$ \\
\hline & & $50 \%$ & 75 & $25.54 \pm 0.24^{\mathrm{gh}}$ & $5.72 \pm 0.00^{\mathrm{klm}}$ & $9.04 \pm 0.01^{\mathrm{klm}}$ \\
\hline & & $70 \%$ & 85 & $8.43 \pm 0.57^{\mathrm{n}}$ & $5.70 \pm 0.08^{\mathrm{km}}$ & $2.81 \pm 0.16^{\mathrm{kl}}$ \\
\hline & & $50 \%$ & 85 & $18.03 \pm 1.15^{\mathrm{l}}$ & $9.96 \pm 0.13^{\mathrm{ij}}$ & $6.93 \pm 0.17^{\mathrm{ij}}$ \\
\hline
\end{tabular}

Data: mean and standard deviations Mean values with different superscripts within the same column are significantly different at $5 \%$ level.

$\mathrm{L}^{*} \quad=$ Lightness, $\mathrm{a}^{*}=$ Redness, and $\mathrm{b}^{*}$ =yellowness. Control=distilled water, $\mathrm{G} 1=70 \%$ ginger concentration, $\mathrm{G} 2=50 \%$ ginger concentration, $\mathrm{A} 1=70 \%$ alligator concentration, $\mathrm{A} 2=50 \%$ alligator pepper concentration

\subsection{Effect Of Spice, Concentrations and Drying Temperatures on the Sensory Attributes of Processed Dried Beef.}

Table 3 displays the sensory attributes of treated and dried beef samples. Significant differences $(p<0.05)$ were observed among all the samples Result for appearance ranged from $4.00-7.17$. Samples treated with $70 \%$ ginger concentration and dried at $85 \mathrm{oC}$ was rated highest in terms of appearance while those treated with $50 \%$ alligator pepper concentration and dried at $65 \mathrm{oC}$ was rated lowest $(4.00 \%)$. With respect to taste, samples treated with $70 \%$ ginger concentration and dried at $850 \mathrm{C}$ was the most preferred, while samples with $50 \%$ alligator pepper concentration and dried at $650 \mathrm{C}$ was the least preferred.

In terms of aroma, samples treated with $70 \%$ ginger concentration and dried at $850 \mathrm{C}$ was the most preferred among others, while beef treated with $50 \%$ alligator pepper concentration and dried at $650 \mathrm{C}$ was rated the lowest. Rating for tenderness for samples treated with $50 \%$ alligator pepper and dried at $75 \mathrm{oC}$ was the highest, while those treated with $70 \%$ ginger and dried at $65 \mathrm{oC}$ was rated the lowest. In terms of mouth feel, samples treated with $70 \%$ ginger concentration and dried at $85 \mathrm{oC}$ were highly appreciated as the highest while samples treated with $70 \%$ alligator pepper concentration and dried at $650 \mathrm{C}$ was least appreciated. Samples treated with $70 \%$ ginger concentration and dried $850 \mathrm{C}$ was recorded the highest values for overall acceptability while those treated sample with $50 \%$ alligatorpepper and dried at $65 \mathrm{oC}$ had the lowest rating for overall acceptability.

Table 3: Effect of Spices, Concentrations and Drying Temperatures on the Sensory Attributes of Dried Beef Samples

\begin{tabular}{|c|c|c|c|c|c|c|c|c|}
\hline Spice & Concentration & $\begin{array}{c}\text { Drying Temperature } \\
\left(C^{0}\right)\end{array}$ & $\begin{array}{c}\text { Appearance } \\
(\%)\end{array}$ & Taste $(\%)$ & Aroma $(\%)$ & $\begin{array}{c}\text { Tenderness } \\
(\%)\end{array}$ & $\begin{array}{c}\text { Mouth feel } \\
(\%)\end{array}$ & $\begin{array}{c}\text { Overall } \\
\text { acceptability } \\
(\%)\end{array}$ \\
\hline Control & & 65 & $6.53 \pm 1.68^{\mathrm{a}}$ & $5.70 \pm 2.20^{\mathrm{bcd}}$ & $5.60 \pm 1.69^{\mathrm{ab}}$ & $5.73 \pm 1.57^{\mathrm{ab}}$ & $5.46 \pm 2.14^{\mathrm{bcd}}$ & $5.96 \pm 1.97^{\mathrm{abcd}}$ \\
\hline Ginger & $70 \%$ & 65 & $4.38 \pm 2.36^{\mathrm{b}}$ & $4.92 \pm 2.32^{\mathrm{de}}$ & $5.42 \pm 2.41^{\mathrm{abc}}$ & $4.50 \pm 2.11^{\mathrm{c}}$ & $4.33 \pm 1.97^{\mathrm{e}}$ & $5.41 \pm 1.86^{\mathrm{cde}}$ \\
\hline & $70 \%$ & 65 & $4.83 \pm 2.39^{\mathrm{b}}$ & $5.77 \pm 1.76^{\mathrm{bcd}}$ & $6.10 \pm 1.84^{\mathrm{ab}}$ & $5.47 \pm 2.24^{\mathrm{abc}}$ & $5.60 \pm 1.90^{\mathrm{bcd}}$ & $5.93 \pm 2.19^{\mathrm{abcd}}$ \\
\hline & $70 \%$ & 75 & $4.93 \pm 1.89^{\mathrm{b}}$ & $5.40 \pm 1.90^{\mathrm{cde}}$ & $5.46 \pm 1.16^{\mathrm{abc}}$ & $5.50 \pm 1.61^{\mathrm{bcde}}$ & $5.16 \pm 2.00^{\mathrm{cd}}$ & $5.46 \pm 1.75^{\mathrm{abcd}}$ \\
\hline & $70 \%$ & 75 & $4.70 \pm 2.00^{\mathrm{b}}$ & $5.10 \pm 1.86^{\mathrm{bcd}}$ & $5.43 \pm 1.61^{\mathrm{abc}}$ & $5.30 \pm 2.04^{\mathrm{cde}}$ & $5.23 \pm 2.04^{\mathrm{cd}}$ & $5.16 \pm 2.05^{\mathrm{bcde}}$ \\
\hline & $70 \%$ & 85 & $7.17 \pm 0.95 \mathrm{a}$ & $7.10 \pm 1.56^{\mathrm{a}}$ & $6.70 \pm 1.49^{\mathrm{a}}$ & $6.20 \pm 1.58^{\mathrm{a}}$ & $6.73 \pm 1.70^{\mathrm{a}}$ & $6.90 \pm 0.99^{\mathrm{a}}$ \\
\hline & $70 \%$ & 85 & $6.70 \pm 1.21^{\mathrm{a}}$ & $6.36 \pm 1.38^{\mathrm{a}}$ & $6.30 \pm 1.12^{\mathrm{ab}}$ & $6.13 \pm 1.14^{\mathrm{a}}$ & $6.43 \pm 1.65^{\mathrm{a}}$ & $6.46 \pm 1.10^{\mathrm{a}}$ \\
\hline
\end{tabular}


International Journal of Science and Research (IJSR)

ISSN (Online): 2319-7064

Index Copernicus Value (2016): 79.57 | Impact Factor (2015): 6.391

\begin{tabular}{|c|c|c|c|c|c|c|c|c|}
$\begin{array}{c}\text { Alligator } \\
\text { Pepper }\end{array}$ & $70 \%$ & 65 & $5.00 \pm 2.11^{\mathrm{bc}}$ & $4.96 \pm 2.10^{\mathrm{bc}}$ & $4.96 \pm 2.20^{\mathrm{bcd}}$ & $5.06 \pm 2.27^{\mathrm{bc}}$ & $5.10 \pm 2.18^{\mathrm{abc}}$ & $5.00 \pm 1.94^{\mathrm{bc}}$ \\
\hline & $50 \%$ & 65 & $4.00 \pm 1.94^{\mathrm{c}}$ & $4.73 \pm 2.03^{\mathrm{c}}$ & $4.73 \pm 2.12^{\mathrm{bcd}}$ & $5.30 \pm 2.03^{\mathrm{bc}}$ & $4.93 \pm 2.22^{\mathrm{bc}}$ & $4.56 \pm 2.12^{\mathrm{c}}$ \\
\hline & $70 \%$ & 75 & $6.66 \pm 1.42^{\mathrm{a}}$ & $5.73 \pm 1.34^{\mathrm{abc}}$ & $5.60 \pm 1.69^{\mathrm{abc}}$ & $6.16 \pm 1.82^{\mathrm{ab}}$ & $6.23 \pm 1.83^{\mathrm{a}}$ & $6.33 \pm 1.62^{\mathrm{a}}$ \\
\hline & $50 \%$ & 75 & $6.26 \pm 2.11^{\mathrm{a}}$ & $6.10 \pm 1.82^{\mathrm{ab}}$ & $5.60 \pm 1.45^{\mathrm{acc}}$ & $6.43 \pm 1.56^{\mathrm{a}}$ & $4.70 \pm 2.32^{\mathrm{c}}$ & $5.66 \pm 1.93^{\mathrm{abc}}$ \\
\hline & $70 \%$ & 85 & $6.33 \pm 1.29^{\mathrm{a}}$ & $6.20 \pm 1.39^{\mathrm{a}}$ & $5.66 \pm 1.58^{\mathrm{abc}}$ & $6.03 \pm 1.35^{\mathrm{ab}}$ & $6.26 \pm 1.46^{\mathrm{a}}$ & $6.13 \pm 1.25 \mathrm{~b}^{\mathrm{ab}}$ \\
\hline & $50 \%$ & 85 & $5.66 \pm 1.78^{\mathrm{ab}}$ & $5.23 \pm 2.12^{\mathrm{abc}}$ & $4.90 \pm 1.95^{\mathrm{bcd}}$ & $5.56 \pm 1.43^{\mathrm{abc}}$ & $5.93 \pm 1.72^{\mathrm{ab}}$ & $5.53 \pm 1.65^{\mathrm{abc}}$ \\
\hline
\end{tabular}

Mean values with different superscripts within the same column are significantly different at $5 \%$. Control $=100 \%$ distilled water, $\mathrm{G} 1=70 \%$ ginger concentration, $\mathrm{G} 2=50 \%$ ginger concentration, $\mathrm{A} 1=70 \%$ alligator pepper concentration, $\mathrm{A} 2=50 \%$ alligator pepper concentration

\subsection{Discussion}

One of the primary objectives of meat preservation is to prolong shelf-life while adding value to meat in terms of quality. The process will not be complete until the resulting products meet the general acceptability of the consumers in terms of taste, color, texture and nutritional value. Among several methods that have been reported to be available, use of drying methods as well as non-synthetic means through the use of natural plant materials have been reported to be effective $[22,4]$

Also, the overall acceptability preference for beef treated with $70 \%$ ginger concentration and dried at $75^{\circ} \mathrm{C}$ is inconsistent with the finding of [19].

\section{Conclusion}

Deduction from the sensory evaluation revealed that $50 \%$ ginger concentration at $85^{\circ} \mathrm{C}$ was more preferred for appearance, taste, aroma, tenderness and overall acceptability than others.

\subsection{Acknowledgement}

Authors are extremely grateful to the staff the Department of Food Science and Technology, the West Africa Agricultural Productivity Program (WAAPP) 1C Sierra Leone Scholarship and Sierra Leone Agricultural Research Institute for their unflinching financial support

\section{References}

[1] Adedeji, T.O. and Ade-Omowaye B.I.O."The preservative effects of two local Nigerian spices on the shelf life of fried bean cake snacks". Journal of nutrition and Food science, 2013, Pp: 2155-9600.

[2] Adegoke, G.O. and Skura, B. J."Nutritional profile and antimicrobial spectrum of the spice Aframoniumdanielli”. Plant Foods Human Nutrition, 1994, pp: 175-182.

[3] Aymerich, T., Picouet, P. A. and Monfort, J. M. 2008. "Decontamination technologies for meat products". Meat Science, 2008, pp:114-129.

[4] Bhaskar, R.K., Deo, K. K., Neupane, U., Bhaskar, S.C., Yadav, B. K., Pokharel, H. P., and Pokharel, P. K."A Case Control Study on Risk Factors Associated with Low Birth Weight Babies in Eastern Nepal".
The sensory evaluation of food product to any food processing technology is very important in determining the consumer acceptability [15]. From the varied perception of consumers acceptability of products in terms of appearance, taste, tenderness, aroma, mouth-feel, and overall acceptability in this study, there was an indication that ginger and alligator pepper treated samples were more accepted than the control in terms of taste, aroma, and others. The overall acceptability indicated more preference in samples treated with ginger than alligator pepper despite variation in color but with more lighter ones than the rest. This is in agreement with facts that spices are believed to have medicinal value and have determinative influences on the overall organoleptic analysis when used [ 23]. Improvement in appearance, flavor, taste, and mouthfeel of the beef samples treated with ginger solution at $70 \%$ concentration and dried at $75^{\circ} \mathrm{C}$ were also reported by) $[20$, 16].

International Journal of Pediatrics, 2015, Article ID 807373,

[5] Dale, R.W. 2011. Ph. D. "Thesis on Meat Processing: Dried, cured, and smoked meats. Center for Meat Safety and Quality"Colorado State University,2011.

[6] Doherty, V.F., Olaniran, O.O. and Kanife, "Antimicrobial activities of Afromomummelegueta (Alligator pepper)". International Journal of Biology, 2010, PP:126- 131 .

[7] Eyo, A.A."Fish processing technology in the tropics". University of Ibadan Press 2001, pp165 - 168.

[8] Faustmann, C. and Casens, R.G. 1990. The biochemical basis for discoloration in fresh meat: A Review. Journal of muscle foods 1(3):217-243

[9] Galal, A.M."Antimicrobial activity of 6-paradol and related compounds". International Journal of Pharmacognosy, 1996, pp:37-43

[10]Heinz, G., and Hautzinger, P."Meat Processing Technology. For Small-To Medium scale Producers". Food and Agriculture Organization of the United Nations Regional Office for Asia and the Pacific 2007. ftp://ftp.fao.org. (Accessed: 1st June 2010).

[11] Kim, K.J. and Lee, Y.B. "Effect of ginger rhizome extract on tenderness and shelf life of pre-cooked lean beef". Asian Australian Journal of Animal Science, 1995 pp:343-346.

[12]Lafont, J., Jacquant, P., Raymond A. and Safaraji, J."Some biological effects of spices, aromatic condiments and other plant products on bacteria and micromycetes, microbial aliment". Journal of Nutrition1984 pp:239-246.

[13] Lambert, A.D., Smith, J.P. and Dodds, K.L."Shelf life extension and microbilolgical safety of fresh meat". A review Food microbiology, 1991, pp:267-297.

[14] Miller, M.D., Anton, A.S., Lamy, P.D. and Cherrington, J.M.."Human Immuno deficiency Virus type 1". Journal of Infectious Disease, 1999, pp: 92-100.

\section{Volume 6 Issue 12, December 2017}




\section{International Journal of Science and Research (IJSR) \\ ISSN (Online): 2319-7064 \\ Index Copernicus Value (2016): 79.57 | Impact Factor (2015): 6.391}

[15] Mohammed, R. ; Khorasani, R. G. ; Goonewardene, L. A. ; Kramer, J. K. G. ; Kennelly, J. J."Persistency of milk trans-18:1 isomers and rumenic acid in Holstein cows over a full lactation". Can. J. Anim. Sci. 2011, pp: 147-167.

[16] Naveena, B.M. and Mendiratta S.K. "Tenderization of spent hen meat using Ginger extract". Brit. Poultry Science, 2001, pp:344-350.

[17] Osuntogun, B. and Aboaba, O.O. "Microbiological and physiochemical evaluation of some non-alcoholic beverages'. Pak. Journal of Nutrition, 2004, pp:188192.

[18] PapassoTshalaba 2000 "A case of suppressor/cytotoxic $\mathrm{T}$ cell lymphoma originating from the skin and revealing a rapid clinical course due to DIC.

[19] Ryoba, R.N., Muhikambele, V.R., Mtenga, L.A. and Mgheni, D.M. "Comparative assessment of drying methods, curing agents and meat-cut size on the quality and preservation of meat under rural setting perspectives. Livestock Research for Rural Development". Volume 25, Article \#10. Retrieved June 15, 2016, from http://www.lrrd.org/lrrd25/1/ryob25010.htm

[20] Syed, Z. K., Rao, D.N. and Amla, B.L. "Effect of lactic acid, ginger extract and sodium chloride on electrophoretic pattern of buffalo muscle proteins". Journal of Food Science and Technology,1995Pp: 224226.

[21] Tackie, A.N., Dwuma-Badu, D., Ayim, J.S., Dabrat, K., Knapp, J. E. and Slakin, D.J. 1975. Aldroxylphenylalkanones from Aframoniummelegueta. Phytochemistry 14: 853 - 854.

[22] Thompson, E.H., Wolf, I.D. and Allen, C.E. 1973. "Ginger rhizome: A new source of proteolytic enzyme". Journal of Food Science, 1973, Pp: 652-655.

[23] Wood, C.D., Manno, J.E., Wood, M.J., Manno, B.R. and Mims, M.E. 2000. Comparison of efficacy of ginger with various antimotion sickness drugs. Clinical research practices and drug regulatory affairs, 2000, Pp:129-136.

[24]Zahra, A., Hashmi, M.Z., Malik, R.N. and Ahmed, $\mathrm{Z}$."Enrichment and geo-accumulation of heavy metals and risk assessment of sediments of the KurangNallah-feeding tributary of the Rawal Lake Reservoir Pakistan”. Science of the Total Environment 2014, Pp:925-933.

[25]Zhou, G.H., Xu, X. L. and Liu, Y. "Preservation technologies for fresh meat-A review". Meat Science, 2010, Pp:119-128

Volume 6 Issue 12, December 2017 www.ijsr.net 